\title{
OCCURRENCE AND VARIABILITY OF CRENICICHLA SAXATILIS (LINNAEUS, 1758) IN SURINAM, AND RESTRICTION OF ITS TYPE- LOCALITY (PISCES, PERCIFORMES, CICHLIDAE)
}

\author{
by \\ A. PLOEG \\ Institute of Taxonomic Zoology (Zoölogisch Museum), University of Amsterdam, \\ P.O. Box 20125, 1000 HC Amsterdam, The Netherlands
}

\begin{abstract}
The South American cichlid species Crenicichla saxatilis (Linnaeus, 1758) is redescribed and figured. The variability of colour pattern, and meristic and morphometric characters are recorded, based on examination of hundreds of specimens from Surinam, including the lectotype. The morphometric characters are tested on validity and discussed.

The distribution of $C$. saxatilis in Surinam is delimited, and the type-locality is restricted to Carolina (= Malasie) Creek, Suriname River system.

Remarks on the status of Crenicichla saxatilis albopunctata Pellegrin, 1904, and of Crenicichla alta Eigenmann, 1912, are included.
\end{abstract}

\section{RÉSUMÉ}

Le Cichlide sud-américain Crenicichla saxatilis (Linnaeus, 1758) est redécrit et figuré. On s'occupe de la variabilité de la coloration et des caractères méristiques et morphométriques, en se basant sur l'examination de centaines d'exemplaires du Surinam, lectotype y-compris. Les caractères morphométriques sont discutés, leur validité testée.

On établit la distribution de $C$. saxatilis en Surinam et la localité-type est restreinte au Carolina (= Malasie) Creek, bassin de la Rivière Surinam.

Sont inclues des remarques sur le statut de Crenicichla saxatilis albopunctata Pellegrin, 1904, et de C. alta Eigenmann, 1912.

\section{INTRODUCTION}

An initial attempt to identify Crenicichla species from several rivers in Surinam yielded problems concerning Crenicichla saxatilis (Linnaeus, 1758). Eigenmann (1912: 516-517) and LoweMcConnell (1969: 292-293) emphasized that two species might be concerned, viz.: $C$. saxatilis and $C$. alta Eigenmann, 1912, which are distinguishable mainly by the number of scales and by the position of the humeral blotch.
Crenicichla saxatilis was originally diagnosed as Sparus saxatilis by Linnaeus (1758), based upon two previously published descriptions: (a) his own description (1754: 65), and (b) Gronovius' description (1756: 29, species nr. 185). Both mention Surinam as locality.

Bloch (1792: 79) assigned Sparus saxatilis to the genus Perca Linnaeus, 1758, and provided a more detailed description than that of Linnaeus. Heckel (1840: 416) established the genus Crenicichla, incorporating Perca saxatilis.

Pellegrin (1904: 374) described a subspecies of $C$. saxatilis: $C$. saxatilis albopunctata. This subspecies was synonymized with $C$. saxatilis by Regan (1905: 159-160) and Eigenmann (1912: 514).

Eigenmann originally described $C$. alta (1912: 516-517) after comparison of his specimens with Bloch's description. However, Eigenmann expressed his doubts concerning $C$. alta, stating: "I secured two forms of Crenicichla resembling saxatilis. One is found along the coast and inland to Rockstone, the other from Rockstone on upward..." and "It will require a larger series of Amazonian specimens than there are on hand at present to determine whether the Amazonian forms are all saxatilis, or whether one of them is the species found in the upland of Guiana. I therefore give only that part of the synonymy and bibliography which undoubtedly refers to saxatilis, and provisionally describe the upland species as new".

Wheeler (1958: 226) redescribed the Gronovian syntype of $C$. saxatilis and stated that, according to Lönnberg, the Linnaean syntype was not in the Museum of the University of Upsala. He assumed the Linnaean syntype was not 
existing anymore. However, Kullander rediscovered two specimens, described by Linnaeus (1754), in the Stockholm collection. So, there appear to be three syntypes instead of two (see also Fernholm \& Wheeler, 1983: 255).

\section{ACKNOWLEDGEMENTS}

Rich material present in the Institute of Taxonomic Zoology (Zoölogisch Museum), Amsterdam (ZMA) (Dr. H. Nijssen) was available for study, collected mainly during the Brokopondo Research Project during 19661967 in nearly all large rivers in Surinam. Additional material was made available by the Field Museum of Natural History (FMNH), Chicago (Dr. D. J. Stewart), the Institut Royal des Sciences Naturelles de Belgique (IRSNB), Brussels (Dr. J. P. Gosse and Mr. L. Walschaerts), the Muséum National d'Histoire Naturelle (MNHN), Paris (Dr. M. L. Bauchot and Mr. F. d'Aubenton), the Rijksmuseum van Natuurlijke Historie (RMNH), Leiden (Drs. M. J. P. van Oijen), and the Naturhistoriska Riksmuseet (NRM), Stockholm (Dr. S. O. Kullander).

I wish to express my gratitude to these curators. Mr. J. Zaagman is thanked for drawing the figures, Mr. L. A. van der Laan for photographing the specimens, the University of Amsterdam, Dr. H. Nijssen and Dr. I. J. H. Isbrücker for their encouraging support.

\section{DEFINITIONS OF TERMS (Fig. 1)}

cf Correlation coefficient.

DCP Least depth of caudal peduncle (expressed as percentage of SL).

HD Head depth, measured just in front of first dorsal spine (expressed as percentage of SL).

HL Head length, measured from distal tip of lower jaw to posterior margin of opercle (expressed as percentage of SL).

HW Head width, measured just beyond orbital rim (expressed as percentage of SL).

LCP Length of caudal peduncle, measured from last anal spine to base of middle caudal fin ray (expressed as percentage of $\mathrm{SL}$ ).

LJL Lower jaw length (expressed as percentage of SL).

LL Lateral line scales.

ORB Length of bony orbit (expressed as percentage of HL).

SL Standard length, measured from distal tip of lower jaw to base of middle caudal fin ray ( $\mathrm{mm}$ ).

SN Snout length, measured from distal tip of upper jaw to edge of bony orbit (expressed as percentage of SL).

TL Total length, measured from distal tip of lower jaw to end of caudal fin ( $\mathrm{mm}$ ).

UJL Upper jaw length (expressed as percentage of SL).
WI Least width of interorbital area (expressed as percentage of $\mathrm{HL}$ ).

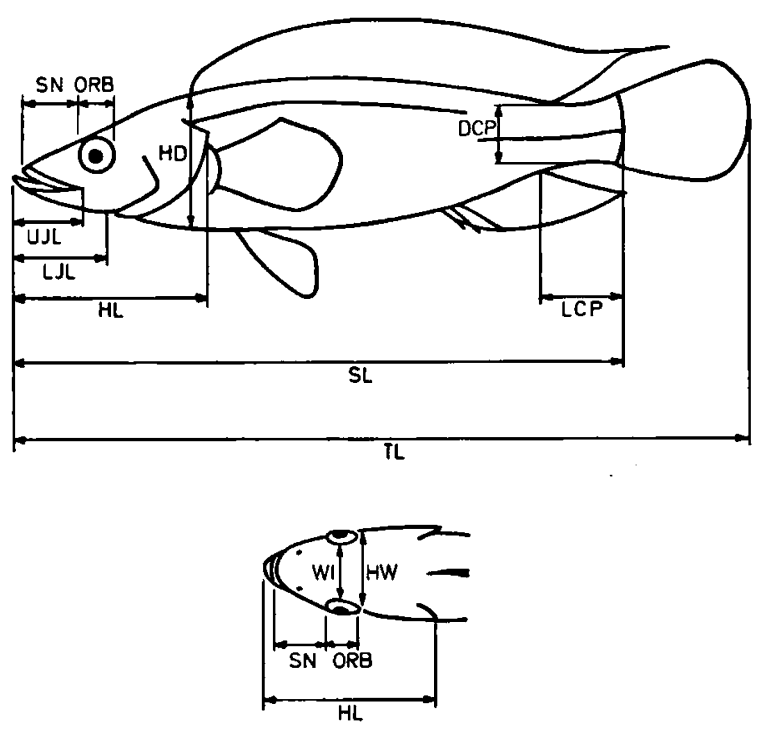

Fig. 1. Diagram showing methods of taking measurements.

Crenicichla Heckel, 1840

Crenicichla Heckel, 1840: 416-417 (original diagnosis; syntype-species: $C$. vittata, $C$. lenticulata, $C$. adspersa, $C$. lugubris, $C$. fenubris, $C$. johanna, C. macrophthalma, $C$. lepidota, $C$. saxatilis, and $C$. labrina; type-species, by subsequent designation of Eigenmann \& Bray, 1894: 620: $C$. macrophthalma).

\section{Crenicichla saxatilis (Linnaeus, 1758)}

(Figs. 2-5; table I)

Sparus saxatilis Linnaeus, 1758: 278 (original diagnosis; Surinam).

Perca saxatilis; Bloch, 1792: 79, fig. 306 (Surinam). Crenicichla saxatilis; Heckel, 1840: 432 (Surinam);

Regan, 1905: 159 (Surinam); Steindachner, 1915: 572 (Marowijne River); Nijssen, 1967b: 246 (Surinam).

Crenicichla saxatilis albopunctata Pellegrin, 1904: 374 (in part; Surinam).

Crenicichla alta; Nijssen, 1966: 175 (Lake Brokopondo); Nijssen, 1967a: 236 (Suriname River system).

Distribution of $C$. saxatilis in Surinam. Crenicichla saxatilis occurs in the Suriname River system, the Commewijne River system, and in the lower course of the Marowijne River 
system, downstream of Tabbetje Hede $\left(04^{\circ} 45^{\prime} \mathrm{N}\right)$ (fig. 2).

Material. - 629 specimens, all from Surinam [largest one $232 \mathrm{~mm}$ SL (ZMA 106.503)], as follows:

NRM 5583, lectotype (by present designation), 112 mm SL (remaining paralectotypes: NRM 5585 and BMNH 1853.11.12:24, not examined).
Suriname River system:

Upper Suriname River, Gran Rio, tributaries at and around Awadam Fall and Ligorio: ZMA 105.389, 24 specimens, 28-I-1967; ZMA 105.432, 19 specimens, 1I-1967; ZMA 105.528, 18 specimens, 31-I-1967; ZMA 105.540, 2 specimens, 30-I-1967; - Suriname River and tributaries near Botopasi Village: ZMA 107.296, 63 specimens, 21-III-1967; Jenjee Creek: ZMA 105.704, 32 specimens, 21-III-1967; Parwapa Creek: ZMA 105.753, 21 specimens, 20-III-1967; Kwati Watra Creek: ZMA

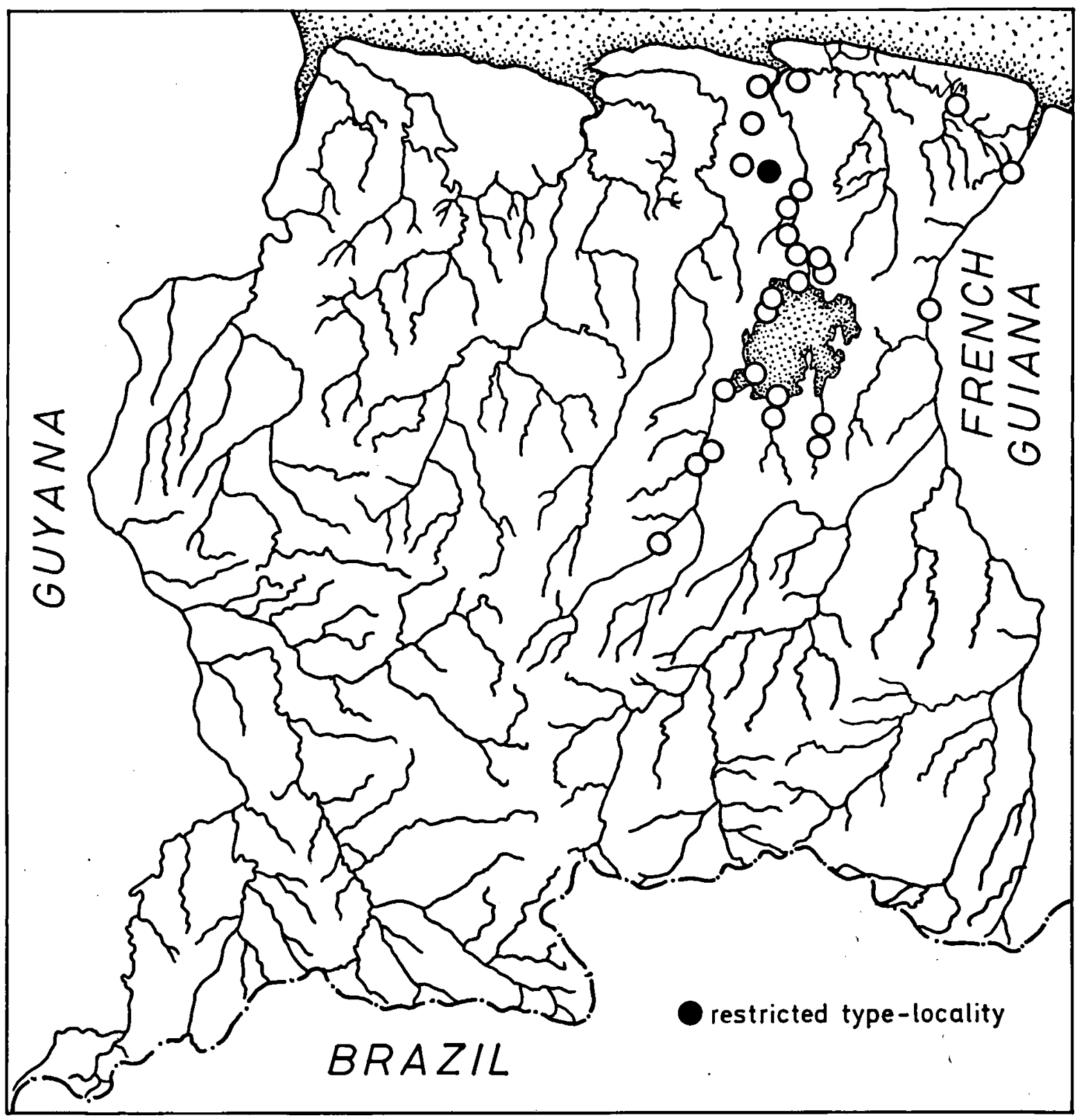

Fig. 2. Distribution of Crenicichla saxatilis in Surinam. 
105.783, 10 specimens, 19-III-1967; - Sara Creek, 31 km S. of Village Dam: ZMA 105.229 and 106.499, 7 specimens, 12-X-1966; 27 km S. of Village Dam: ZMA 105.217, 16 specimens, 14-X-1966; 19-21 km S. of Village Dam: ZMA 106.498 and 106.500, 5 specimens, 12/13-X1966; - Marowijne (=Gran) Creek, tributary to Suriname River, $63 \mathrm{~km}$ S. of Afobaka: ZMA 105.273, 18 specimens, 20-X-1966; $50.5 \mathrm{~km} \mathrm{~S}$. of Afobaka: ZMA 106.501, 3 specimens, 19-X-1966; ZMA 105.107, 25 specimens, 27-X-1966; 53.5-55 km S. of Afobaka: ZMA 106.494, 1 specimen, 25-V-1966; ZMA 106.493 and $105.174,3$ specimens, 24-V-1966; $58-60 \mathrm{~km} \mathrm{~S}$. of Afobaka: ZMA 105.021 and 106.496, 50 specimens, 9VI-1966; ZMA 105.017 and 106.495, 21 specimens, 8VI-1966; - Brokopondo Lake at former Mamadam Fall: ZMA 107.589, 1 specimen, 17/18-XII-1978; Brokopondo Lake, 2 km S.S.W. of former Komkomjee Island: ZMA 107.602, 3 specimens, 14-XII-1978; Brokopondo Lake along barrage at Afobaka and along eastern dams: ZMA 105.012, 1 specimen, 13-VI-1966; ZMA 105.320, 2 specimens, 7-VII-1966; ZMA 105.484, 2 specimens, 15-II-1967; ZMA 106.503, 3 specimens, 12 I-1967; Brokopondo Lake, 3.5 km S.E. of Brownsweg: ZMA 105.150, 3 specimens, 31-VIII-1966; Witte Creek, $12 \mathrm{~km} \mathrm{~S}$. of Brownsweg: ZMA 105.263/105.264, 63 specimens, 23-XI-1966; Makambi Creek, $8 \mathrm{~km} \mathrm{S.} \mathrm{of}$ Brownsweg: ZMA 105.113, 14 specimens, 13-IX-1966; Creek near Brownsweg: ZMA 100.733, 1 specimen, X1960; - Creeks into Suriname River near Brokopondo Village: Tapoeripa Creek: ZMA 105.100, 29 specimens, 25-VIII-1966; ZMA 105.154, 5 specimens, 15-IX-1966; - Dabikwen Creek: ZMA 105.128, 37 specimens, 19-IX1966; - Compagnie Creek: ZMA 105.063, 3 specimens, 22-VIII-1966; - Mama Creek into Suriname River near Berg en Dal: ZMA 105.061, 6 specimens, 2-IX-1966; ZMA 106.491, 1 specimen, 2-V-1966; - Klaas Creek into Suriname River: ZMA 105.064 and 106.497, 6 specimens, 2-IX-1966; - Marchall Creek into Suriname River: ZMA 105.316, 27 specimens, 8-XII-1966; ZMA 105.076, 4 specimens, 23-VIII-1966; - Carolina Creek, tributary to Para River: ZMA 106.502, 39 topotypes, 14XII-1966; - Coropina Creek near Republiek: ZMA 112.556, 1 specimen, 5-XI-1972; - Zanderij: IRSNB 19569, 3 specimens, 26-VI-1966; - Tout Lui Faut Canal, $12 \mathrm{~km} \mathrm{S.} \mathrm{of} \mathrm{Paramaribo:} \mathrm{ZMA} \mathrm{105.312,} 33$ specimens, 12-XII-1966; - Ditches in Botanical garden in West Paramaribo: ZMA 105.311, 1 specimen, 12-XII1966; Paramaribo: ZMA 100.727, 1 specimen, VIII1951; Charlottenburg, N. of Paramaribo: ZMA 100.264, 4 specimens, 2-VIII-1948.

Commewijne River system:

Ricanau Creek, $5 \mathrm{~km} \mathrm{E}$. of Moengo, at road to Albina: ZMA 112.555, 2 specimens, 6-XI-1972.

Marowijne River system:

Marowijne River at Tabbetje Hede: IRSNB 19567, 8 specimens, 24-XI-1966; - Nengre Creek into Marowijne
River near Albina: IRSNB 19568, 2 specimens, 26-XI-1966.

Restriction of the type-locality of Crenicichla saxatilis (Linnaeus, 1758). - According to Linnaeus (1758: 279), C. saxatilis originates from Surinam. Examination of hundreds of specimens from nearly all large rivers in Surinam proved that $C$. saxatilis neither occurs in rivers west to the Suriname River system, nor in the Marowijne River upstream of Tabbetje Hede (about $04^{\circ} 45^{\prime} \mathrm{N}$ ). However, other Crenicichla species, which are closely related to C. saxatilis, are present in these rivers. Consequently, it is necessary to restrict the typelocality of $C$. saxatilis. A large series (ZMA 106.502) with males, females, and juveniles is selected as the basis to restrict the type-locality: Carolina Creek, tributary to Para River, Suriname River system, Surinam.

Description. - Based primarily on a $183 \mathrm{~mm}$ SL male from the type-locality. The description also includes data from 24 specimens of the same sample (morphometric data of this material in table I).

Elongate; trunk rectangular; laterally compressed; head not flattened; snout in this specimen rounded, in many others pointed; lips broad; nostrils situated just between postlabial skinfold and orbit; maxilla reaching to below orbit; caudal peduncle almost as deep as long; preoperculum serrated.

Teeth conical, directed backwards, with red crowns; five rows of teeth in lateral part of upper jaw, four rows in lateral part of lower jaw; in smaller specimens less rows of teeth, in specimens larger than about $80 \mathrm{~mm}$ SL always one row more in upper than in lower jaw; in specimens smaller than about $80 \mathrm{~mm}$ SL two rows in both jaws; in upper jaw all teeth equal in length; in lower jaw outer teeth the largest; in both jaws only outer row of teeth fixed, inner row(s) evertible.

Scales ctenoid, except for cycloid scales present on cheek, operculum, and head (ventrally and dorsally above anterior part of lateral line); lateral line scales larger than adjacent 
BIJDRAGEN TOT DE DIERKUNDE, 56 (1) - 1986

TABLE I

Morphometric data of Crenicichla saxatilis from Surinam.

\begin{tabular}{|c|c|c|c|c|c|c|c|c|c|}
\hline & & \multicolumn{2}{|c|}{$\begin{array}{l}\text { NRM } 5583 \\
\text { Lectotype } \\
\text { C.s.saxatilis }\end{array}$} & \multicolumn{2}{|c|}{$\begin{array}{c}\text { ZMA } 106.502 \\
\text { adult male } \\
\text { Carolina Creek }\end{array}$} & \multicolumn{2}{|c|}{$\begin{array}{l}\text { MNHN } 4083 \\
\text { syntype } \\
\text { C.s.albopunctata }\end{array}$} & \multicolumn{2}{|c|}{$\begin{array}{c}\text { ZMA } 106.50224 \text { specimens } \\
\text { Carolina Creek (75-184 mm SL) }\end{array}$} \\
\hline & & $\mathbf{m m}$ & $\% \mathrm{SL}$ & $\mathrm{mm}$ & $\% \mathrm{SL}$ & $\mathrm{mm}$ & $\% \mathrm{SL}$ & $\bar{x} \% \mathrm{SL}$ & range\% SL \\
\hline SL & & 111 & & 183 & . & 170 & & & \\
\hline HL & $\cdot$ & 35 & $(31.5)$ & 61 & (33.3) & 57 & $(33.5)$ & 32.5 & $30.7-34.6$ \\
\hline HD & & 24 & $(21.6)$ & 45 & $(24.6)$ & 35 & $(20.6)$ & 22.2 & $20.0-24.6$ \\
\hline HW & & 14 & $(12.6)$ & 27 & (14.8) & 22 & (12.9) & 13.3 & $12.1-14.8$ \\
\hline DCP & & 13 & (11.7) & 23 & (12.8) & 19 & (11.2) & 11.5 & $10.3-12.6$ \\
\hline LCP & & 12 & (10.8) & 22 & $(12.0)$ & - & - & 11.2 & $9.9-12.1$ \\
\hline SN & & 10 & $(9.2)$ & 20 & $(10.9)$ & 18 & $(10.6)$ & 9.9 & $8.3-10.9$ \\
\hline UJL & & 14 & (12.4) & 26 & $(14.2)$ & - & - & 13.0 & $11.5-14.3$ \\
\hline LJL & & 20 & (18.1) & 33 & (18.0) & - & - & 17.3 & $13.9-18.8$ \\
\hline ORB & & 7.0 & $\begin{array}{c}\% \text { HL } \\
(20.0)\end{array}$ & 10.6 & $\begin{array}{l}\% \text { HL } \\
(17.4)\end{array}$ & 9.3 & $\begin{array}{l}\% \text { HL } \\
(16.3)\end{array}$ & $\begin{array}{l}\% \mathrm{HL} \\
21.2\end{array}$ & $\begin{array}{l}\text { range } \% \mathrm{HL} \\
16.9-24.8\end{array}$ \\
\hline WI & & 7.8 & $(22.4)$ & 18 & $(29.5)$ & 15 & $(26.3)$ & 23.2 & $17.1-29.5$ \\
\hline
\end{tabular}

scales; two, occasionally three scales in a vertical row between the lateral lines; 22 in anterior, and 11 in posterior lateral line, in 23 other specimens: $21 / 10$ (1), 22/9 (2), 22/10 (4), $22 / 11$ (2), 23/10 (7), 23/11 (2), 24/9 (2), and $24 / 10$ (3) (one of the 24 specimens was damaged); two lateral line scales extend on caudal fin, in 24 other specimens: 2 (21) and 1 (3); from operculum to caudal fin base 52 scales in a series below the lateral lines, in 24 other specimens: 52 (4), 53 (1), 54 (6), 55 (4), 56 (3), 57 (2), 58 (2), 59 (1), and 60 (1).

Nine serrated gill rakers, in 15 other specimens: 8 (2) and 9 (13); dorsal four or five rakers bent, the remaining ones are knobshaped.

Dorsal fin origin just beyond posterior edge of operculum; spines increasing in length to seventh, occasionally to eighth or ninth, posterior to which they become equal in length; soft part of dorsal fin acute posteriorly, usually reaching to four-fifth of caudal fin, occasionally to beyond caudal fin, in females not extending to beyond halfway the caudal fin, in juveniles up to about $60 \mathrm{~mm}$ SL reaching to caudal fin base; D XVIII.14, in 24 other specimens: XVII.14 (1), XVII.16 (3), XVIII.14 (5),
XVIII.15 (13), XIX.13 (1), and XIX.15 (1). Anal fin acute posteriorly, reaching to caudal fin base, occasionally (in males) little longer; A III.9, in 24 other specimens: III.9 (11) and III.10 (13). Ventral fin reaching to halfway the anus; second (soft) ray the longest; distally acute; V I.5 in all 25 specimens. Pectoral fin as long as ventral fin; distally rounded; $P 15$ in all 25 specimens. Caudal fin rounded; basal scales present, most in the middle of the fin base (4 scale series versus one scale series dorsally and ventrally); interradial scales extend to onefourth of caudal fin (already present in the smallest specimen examined: $23 \mathrm{~mm}$ SL, ZMA 107.296); C 16 in all 25 specimens.

Colour in alcohol. - Males, females, and juveniles show differences in colour pattern as follows (descriptions based on sample ZMA 106.502):

Male, $183 \mathrm{~mm}$ SL (figs. 3, 4): Brownish; dorsally darker, ventrally lighter; no conspicuous line between these areas; anterior part of head and mouth greyish; preventral area pale; cheek yellowish; pectoral and ventral fins light grey, other fins darker; dark blotch just 


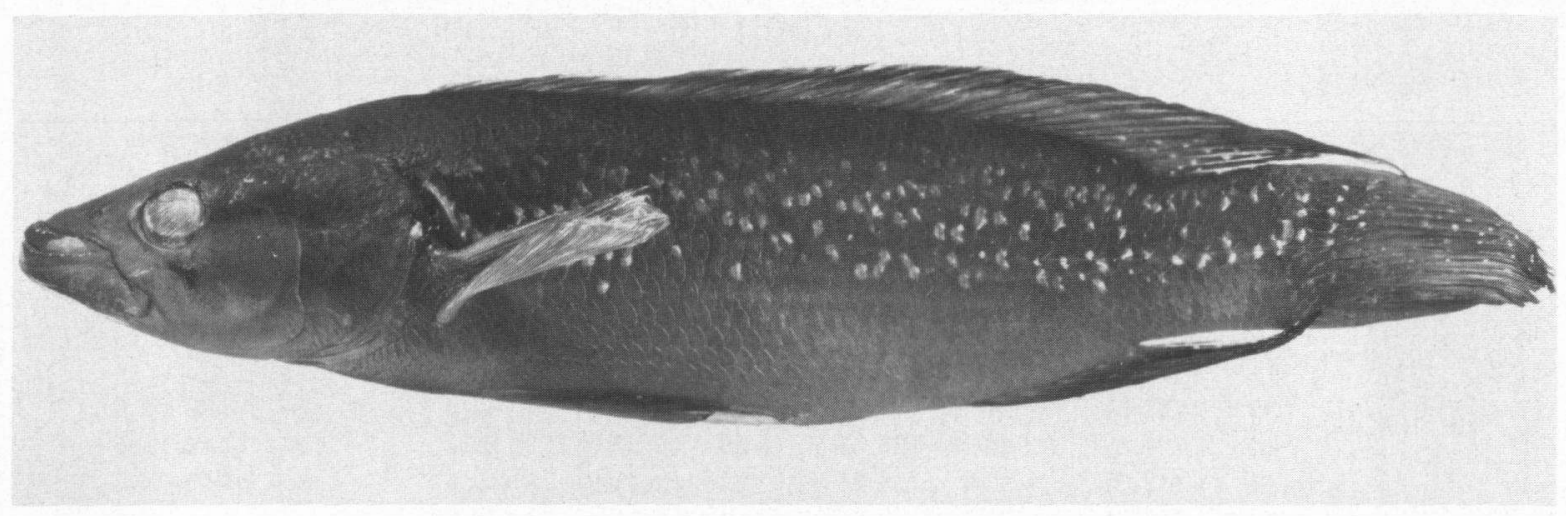

Fig. 3. Crenicichla saxatilis (Linnaeus, 1758), ZMA 106.502 A, $183 \mathrm{~mm}$ SL male from the type-locality.

above lateral line on caudal fin base, covering three rays; dark humeral blotch covering four scales in a horizontal series, just posterior to operculum, just below - in larger upstream specimens occasionally on - lateral line; humeral blotch irregularly round with a notch (fig. 4), always present at upper anterior side; dark suborbital stripe; dark horizontal stripe from orbit to humeral blotch; dark horizontal stripe tapering from orbit to distal tip of jaw;

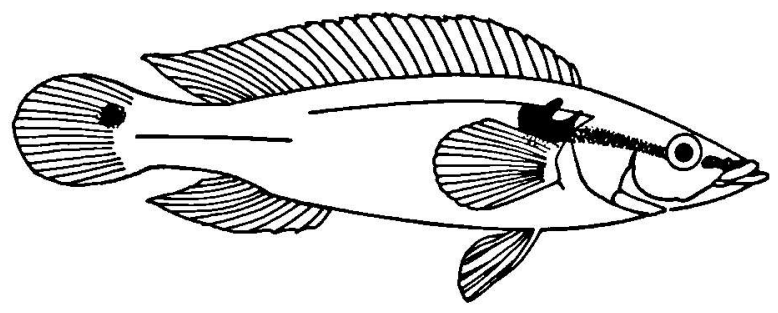

Fig. 4. Position of lateral stripe, humeral blotch, and caudal fin blotch in $C$. saxatilis.

often about nine dark vertical bars above lateral lines; many silvery dots, smaller than a scale, occur in an irregular pattern on darker part of the sides, they are more numerous posteriorly than just beyond operculum; white dots, smaller than dots on sides, in posterior part of dorsal fin, anal fin, and in dorsal lobe of caudal fin; humeral blotch and caudal fin blotch margined by silvery dots, giving the impression of an incomplete ocellus.
Female, $152 \mathrm{~mm}$ SL (fig. 5): Ground colour as in male; humeral blotch only partly margined by silvery dots; no dots on sides; caudal fin blotch hardly visible (in many other females conspicuous); faint dark lateral band; thirteen black ocelli in dorsal fin, posterior to eleventh spine, in other females there are occasionally ocelli a) from first spine to last soft ray, b) in last spines only, and c) no ocelli at all (intermediates occur); dorsal fin margin above ocelli white; caudal fin with dark dorsal margin, five ocelli below this margin; occasionally a black instead of a white margin.

Juvenile, $41 \mathrm{~mm}$ SL: Upper half of the body darker, lower half lighter, with a dark band, running from tip of snout to caudal peduncle; lateral band disappearing with age; humeral blotch on lateral band, below lateral line, round; caudal fin blotch with light margin; dorsal fin with white margin; no ocelli on fins; no dots on sides; caudal fin dorsally with white margin and dark submargin, ventrally with a white margin; dorsal fin with white margin; no ocelli on fins; no dots on sides; caudal fin dorsally with white margin and dark submargin, ventrally with a white margin only; shades of bars above lateral lines.

Lectotype (NRM 5583) of Crenicichla saxatilis (fig. 6, table I). - The lectotype of $C$. saxatilis, one of the Linnaean specimens, agrees in most respects with the characters of the Carolina Creek specimen described above. Differences 




Fig. 5. Crenicichla saxatilis (Linnaeus, 1758), ZMA 106.502 A, $152 \mathrm{~mm}$ SL female from the type-locality.

are not exceeding those within the Carolina Creek sample. The usual data are: scales on lateral lines: 22/9; lateral line extending on caudal fin with two scales; 56 scales in a series below lateral lines; 2 scales in a vertical series between the lateral lines; 10 serrated gill rakers; 5 rows of teeth laterally in upper jaw, 4 laterally in lower jaw; all teeth equal in length; preoperculum serrated.

Posterior part of dorsal fin damaged and therefore reaching only to caudal fin base, D XVIII.14; caudal fin damaged, basal scales and interradial scales as described above, C 16; anal fin reaching to caudal fin base, A III.9; ventral fin: V I.5; pectoral fin: P 15.

Colour of lectotype: Greyish-green; operculum lighter; cheek brownish; anterior part of head and mouth greyish; preventral area pale; neither dots on sides nor humeral blotch visible; only traces of a blotch on the caudal fin are visi- ble on the position described above; no suborbital stripe.

\section{DISCUSSION OF MORPHOMETRIC AND MERISTIC CHARACTERS}

Measuring body depths and body widths of about thirty specimens yielded that there exists too wide a range in variability in these characters, because of intestinal conditions, to be useful as a distinction between species. Instead I measured head depths and head widths.

Correlation of characters with standard length within one sample (figs. $7 a-k$ and $8 a-e$ ):

While comparing small specimens (less than $40 \mathrm{~mm} \mathrm{SL}$ ) with large ones, many characters (expressed as percentages of SL or HL) may vary. To show this variability, scatter

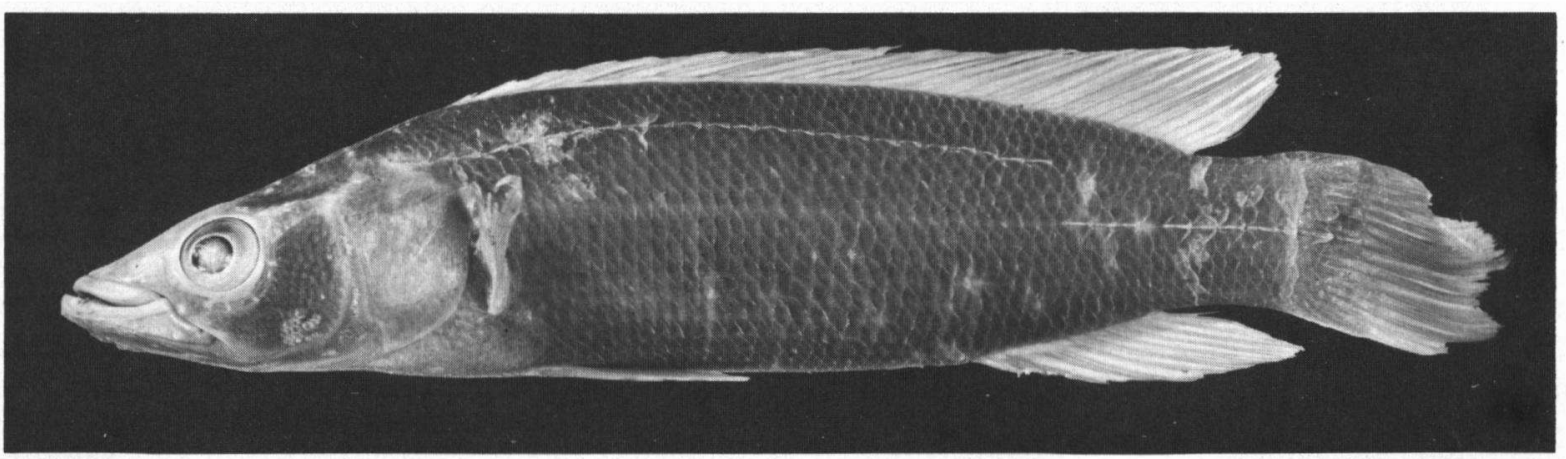

Fig. 6. Crenicichla saxatilis (Linnaeus, 1758), lectotype NRM 5583, $112 \mathrm{~mm}$ SL. 


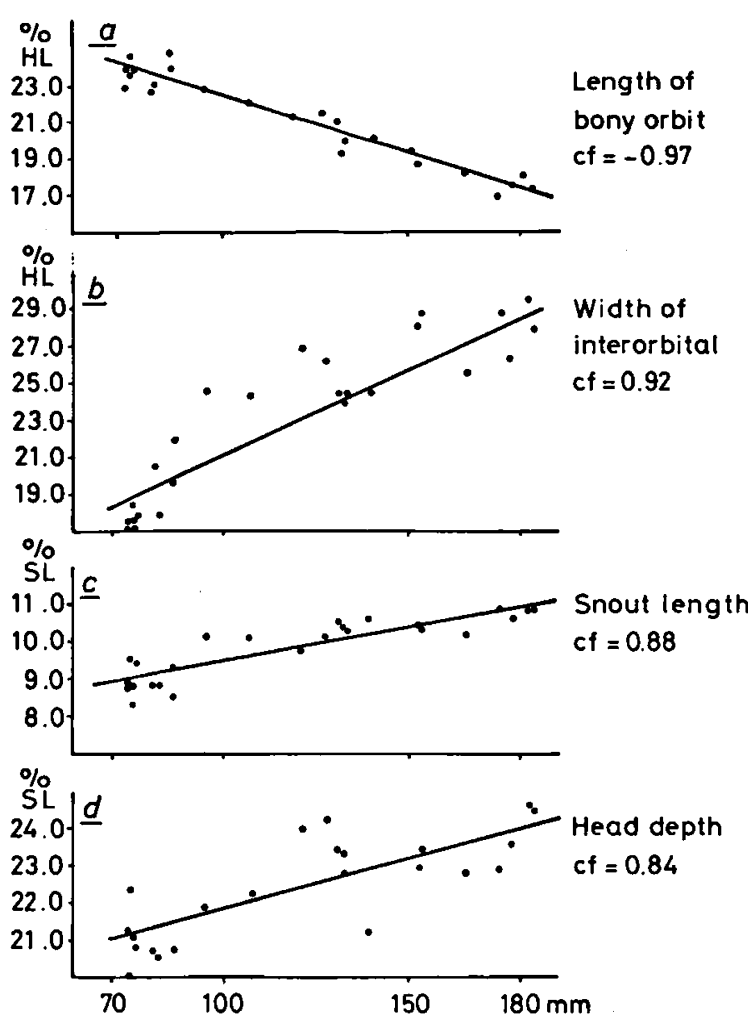

Fig. 7a-d. Characters correlated clearly with standard length.

diagrams, regression lines and correlation coefficients (cf) have been constructed and calculated, which are presented in figs. $7 \mathrm{a}-\mathrm{k}$ (morphometric characters) and in figs. 8a-e (meristic characters).

Four characters proved to be correlated with size (see figs. 7a-d):

a) length of bony orbit (ORB, $\mathrm{cf}=-0.97)$;

b) width of interorbital (WI, $\mathrm{cf}=0.92$ );

c) snouth length $(\mathrm{SN}, \mathrm{cf}=0.88)$;

d) head depth (HD, cf $=0.84$ ).

Three characters tend to show a correlation with size (see also figs. 7e-g):

e) head length ( $\mathrm{HL}, \mathrm{cf}=0.54$ );

f) depth of caudal pecuncle (DCP, $\mathrm{cf}=0.62$ );

g) length of caudal peduncle ( $\mathrm{LCP}, \mathrm{cf}=0.54$ ).

Three characters have no correlation with size or only very little (see figs. $7 \mathrm{~h}-\mathrm{k}$ ):

h) head width ( $\mathrm{HW}, \mathrm{cf}=0.01)$;

i) upper jaw length ( $U J L, c f=0.24)$;

k) lower jaw length $(\mathrm{LJL}, \mathrm{cf}=0.28)$.
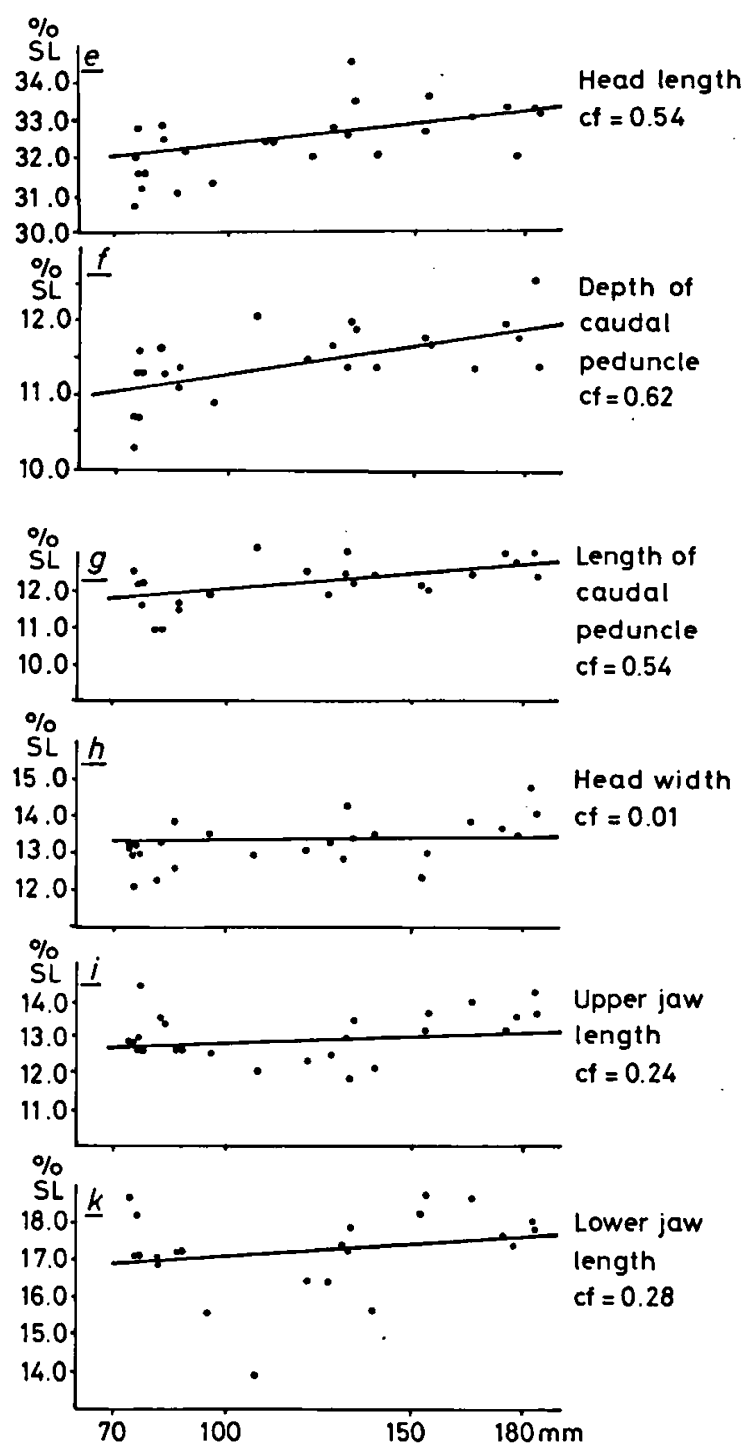

Fig. 7e-g. Characters tending to be correlated with standard length.

Fig. 7h-k. Characters not showing correlation with standard length.

While comparing two samples, the one containing large specimens, the other containing small specimens, only head width (HW), upper jaw length (UJL), and lower jaw length (LJL) seem useful to discriminate.

Meristic characters (see figs. 8a-e) are more independent of size. The numbers of scales in the lateral lines (fig. 8a, $\mathrm{cf}=-0.08$ ), and the 
number of scales along the lateral lines (fig. 8b, $\mathrm{cf}=-0.07$ ) show no correlation with length.

The numbers of dorsal (fig. $8 c, c f=-0.36$ ) and anal rays (fig. $8 \mathrm{~d}, \mathrm{cf}=-0.57$ ) tend to show some correlation with size. Only the numbers of rows of teeth (fig. $8 \mathrm{e}, \mathrm{cf}=0.90$ ) are clearly correlated with size. Young specimens have two rows of teeth laterally in both jaws, larger specimens have more rows, always one row more in upper jaw than in lower jaw. The larger the specimen, the more rows of teeth, up to five in upper and four in lower jaw, laterally.

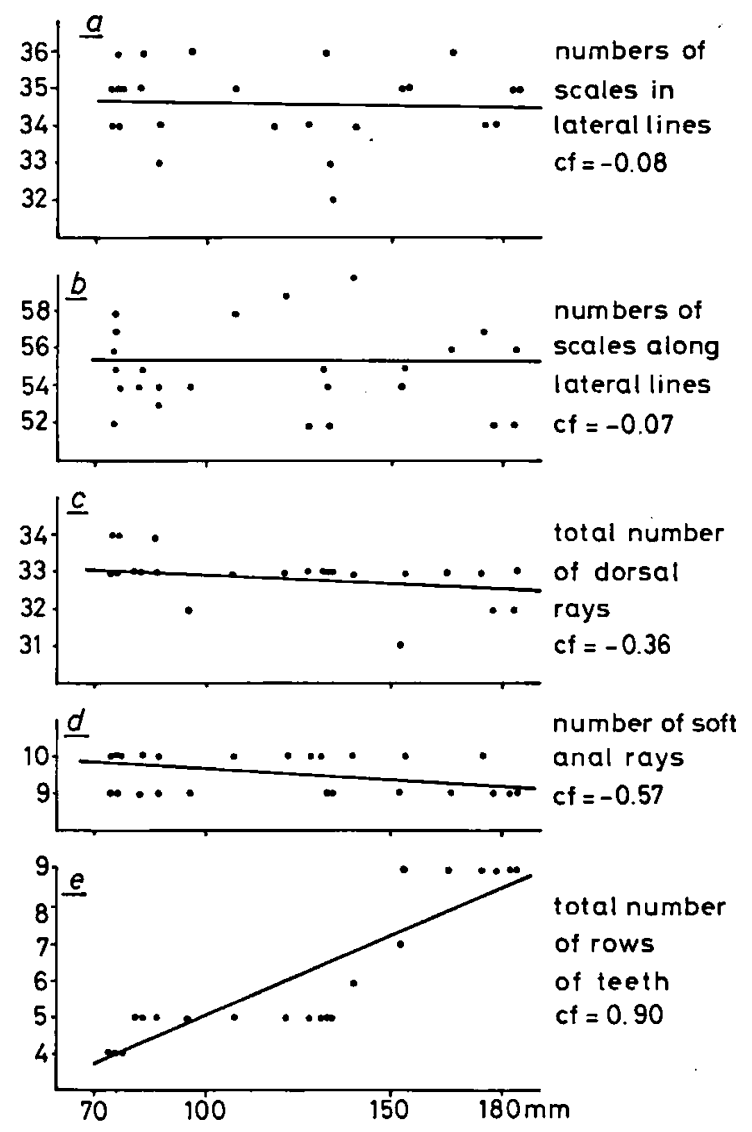

Fig. 8a-e. Correlation of meristic characters with standard length.

Correlation of characters with standard length within the population of the Suriname River (figs. 9, $10 \mathrm{a}-\mathrm{d}$, and 11):

The effect of geographical distribution on the characters was investigated by comparing sam- ples of six localities along the Suriname River (fig. 9): Awaradam, Botopasi, Witte Creek, Marchall Creek, Carolina Creek, and Tout Lui Faut Canal (in south-north direction). Of these samples four characters were compared (figs. $10 \mathrm{a}-\mathrm{d})$ to find a possible clinal variation, viz., head depth (HD), snout length (SN), orbital diameter (ORB), and width of interorbital (WI). Figs. 10a-d show regression lines of the characters on standard length, together with their correlation coefficients. These graphs show that there is no clinal variation. The large

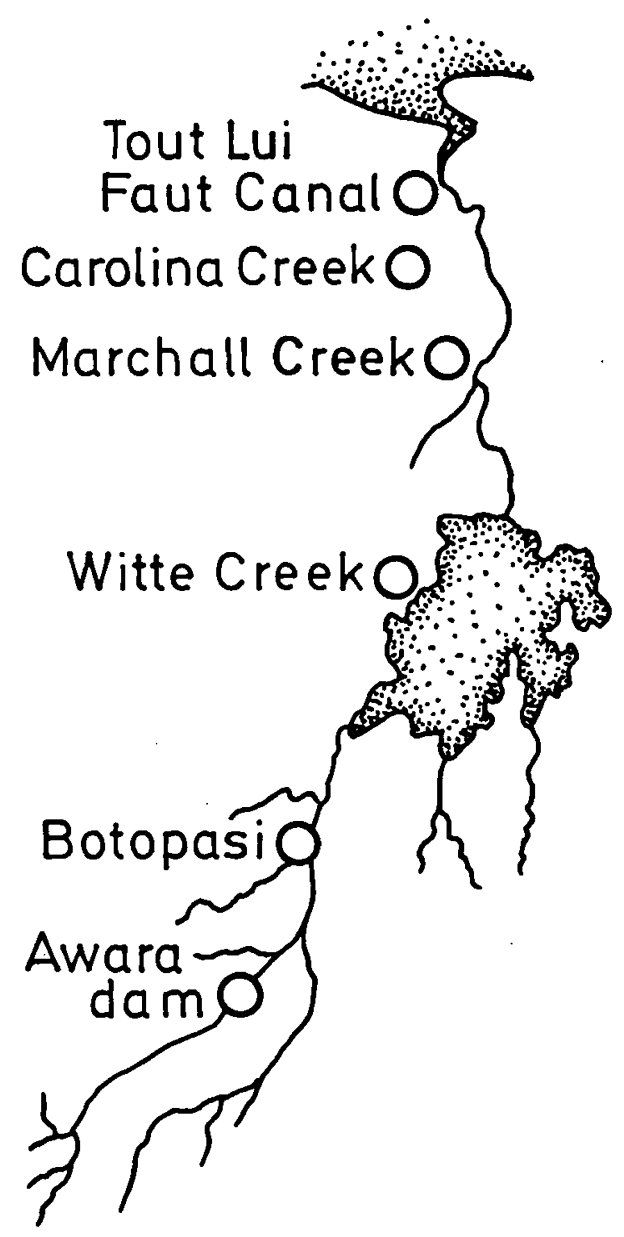

Fig. 9. Map of the Suriname River system, showing the locations of six samples used in our analyses.

variability in the level of the regression lines, and in the slope of the regression lines with the $\mathrm{X}$-axis, is caused by the unbalanced composition of the samples. 


\section{$\underline{a}$}
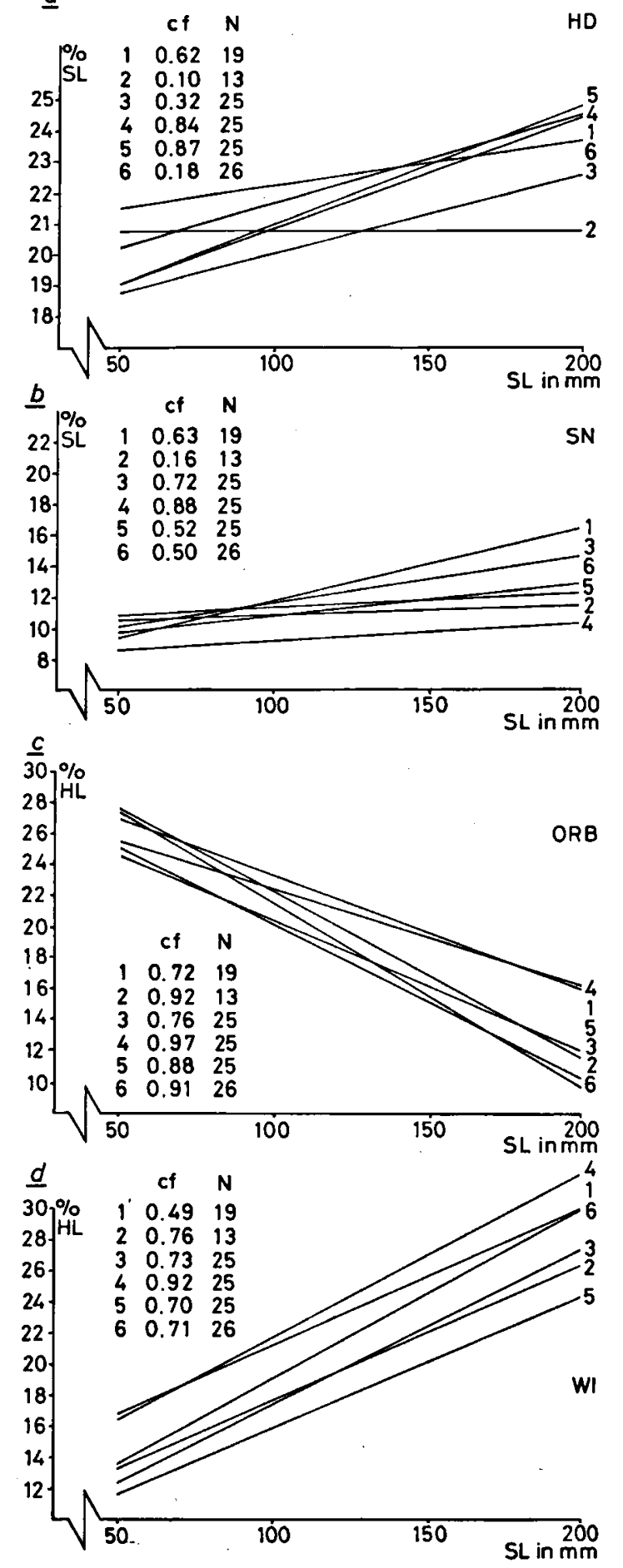

Fig. 10a-d. Regression of HD, SN, ORB, and WI on standard length, with cf-values for the six stations given in fig. 9.

(1 = Awaradam; 2 = Botopasi; 3 = Witte Creek; $4=$ Marchall Creek; 5 = Carolina Creek; 6 - Tout Lui Faut Canal).
When a sample consists of many specimens of about the same length (fig. 11: Botopasi and Tout Lui Faut Canal), the cf-values will be low, whereas the variability in level and slope of regression lines is high. Comparison based on size-correlated characters of samples from different localities is only useful when the sample consists of specimens with balanced size composition.

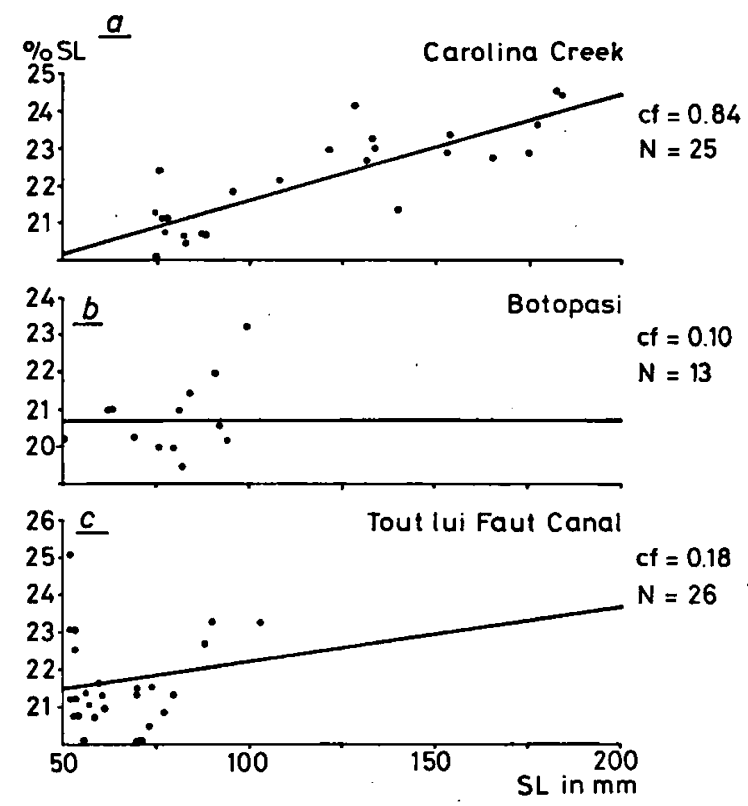

Fig. 11. Distribution of standard length within a sample, showing its effect on regression lines and cf-values in three samples: Carolina Creek, Botopasi, and Tout Lui Faut Canal.

Differences between upstream and downstream specimens (figs. 12a-e):

In some characters there appear to be differences between specimens from the upper Suriname River, and specimens from the lower Suriname River. Upstream specimens have (a) on the average slightly more scales along the lateral lines, (b) on the average one more dorsal fin spine, and (c) on the average slightly higher HD ratios. Figs. 12a-e show histograms of five characters from the same six localities as used before: Awaradam, Botopasi, Witte Creek, Marchall Creek, Carolina Creek, and Tout Lui Faut Canal. According to these histograms two populations seem to be present: an upland 


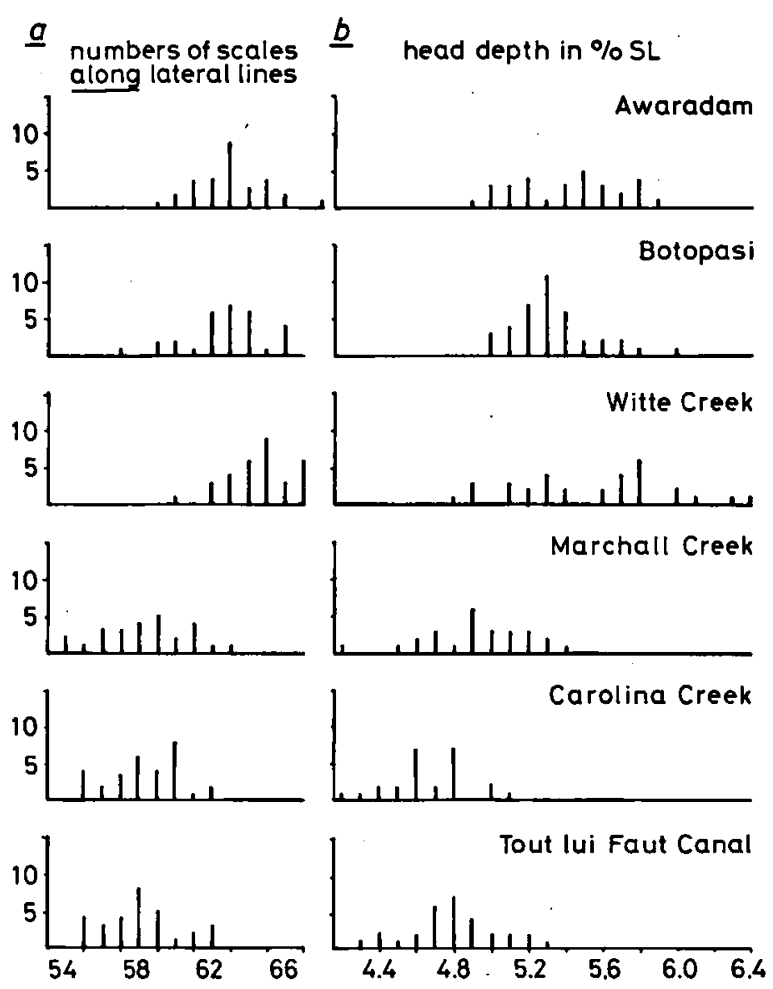

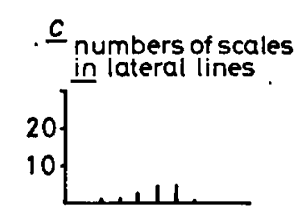
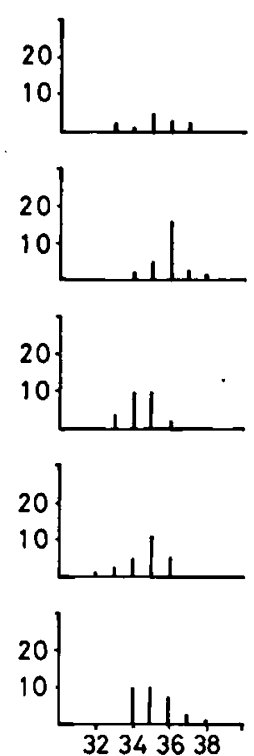

$\underline{e}$ numbers of dorsal rays

(incl. spines)
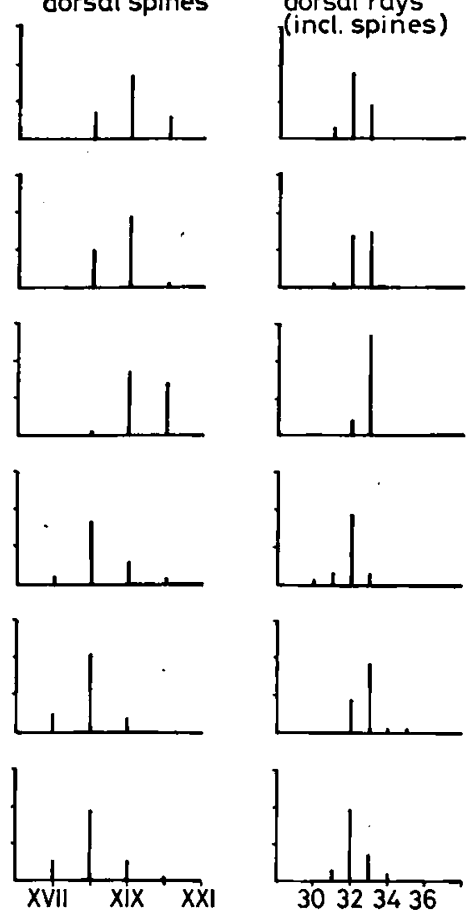

Fig. 12a-e. Histograms of five characters from six stations in the Suriname River (see fig. 9).

population and a lowland population. These two meet in the man-made Lake Brokopondo. Before this lake was established (1965) the Brokopondo rapids may have been a barrier between the populations. At the moment the two populations have such great overlap in characters that (without locality information) only extreme specimens are distinguishable. Therefore, the differences are insufficient to recognize these two populations as two different taxa.

The variation is probably caused by ecological circumstances. Scale number differences in the populations may be explained by the influence of different water temperatures. In many species warmer water accelerates the development of bone and bone-like structures like scales and spines. There is less time for development of scales and spines which results in less numerous scales and spines. In running waters the average temperature is lower than in stagnant waters, thus, more scales and more spines in upland specimens (cooler water) are to be expected. A lower head (lower HD ratio) is a plausible explanation as adaptation to faster running waters. In favour of this hypothesis are the more numerous scales and spines, and more flattened head in upstream species like $C$. multispinosa: about 95 scales along the lateral lines, about 24 dorsal fin spines, and a head depth of about $30 \%$ of SL (versus about 55 scales, 18 dorsal spines, and a head depth of about $32.5 \%$ for $C$. saxatilis).

Crenicichla saxatilis versus Crenicichla alta. - Two distinct populations occur in the Suriname River, viz. an upland and a lowland population. A similar situation occurs in Crenicichla in the Essequibo River; Eigenmann (1912: 514) described the upland taxon as $C$. alta.

I compared $C$. alta (holotype and 15 paratypes) from the Essequibo River with $C$. saxatilis from the upper Suriname River (table II). 


\section{TABLE II}

Morphometric and meristic data of Crenicichla saxatilis from the upper Suriname River (Parwapa Creek), and of Crenicichla alta (holotype and 15 paratypes) from the Essequibo River (Guyana); $\mathrm{SD}=$ standard deviation; $N=$ number of elements.

\begin{tabular}{|c|c|c|c|c|}
\hline & \multicolumn{2}{|c|}{$\begin{array}{l}\text { C. saxatilis : } \\
13 \text { specimens, Parwapa } \\
\text { Creek, Surinam } \\
\text { ZMA } 105.753\end{array}$} & \multicolumn{2}{|c|}{$\begin{array}{l}\text { C. alta } \\
\text { Holotype and } \\
15 \text { paratypes, } \\
\text { (British) Guyana }\end{array}$} \\
\hline & $\bar{x} \% \mathrm{SL}$ & SD & $\bar{x} \% \mathrm{SL}^{\prime}$ & SD \\
\hline HL & 32.4 & 1.06 & 32.9 & 1.68 \\
\hline HD & 20.9 & 1.02 & 18.6 & 1.89 \\
\hline HW & 13.3 & 0.72 & 12.4 & 1.23 \\
\hline DCP & 11.2 & 0.46 & 10.8 & 0.76 \\
\hline LCP & 12.7 & 1.15 & 11.2 & 1.29 \\
\hline SN & 10.7 & 0.63 & 9.9 & 1.57 \\
\hline UJL & 11.0 & 0.66 & 11.5 & 1.27 \\
\hline \multirow[t]{2}{*}{ LJL } & 16.2 & 0.46 & 17.4 & 1.71 \\
\hline & $\bar{x} \% \mathrm{HL}$ & SD & $\bar{x} \% \mathrm{HL}$ & SD \\
\hline ORB & 22.3 & 1.54 & 22.4 & 3.33 \\
\hline \multirow[t]{2}{*}{ WI } & 15.7 & 1.69 & 24.4 & 3.56 \\
\hline & $N$ & SD & $N$ & SD \\
\hline LL & 57.4 & 2.02 & 60.1 & 2.63 \\
\hline D spines & 18.9 & 0.49 & 18.8 & 0.41 \\
\hline soft rays & 13.6 & 0.51 & 13.7 & 0.49 \\
\hline
\end{tabular}

Although the mean lengths of the two samples differ $(92 \mathrm{~mm}$ SL for $C$. saxatilis and $78 \mathrm{~mm}$ SL for $C$. alta) and also the length composition within the two samples, it is possible to distinguish these two by characters which are not correlated with size, like head width and jaw length (table II). Also the shape of the humeral blotch differs. In $C$. alta it is round, and more often on the lateral line than below it. Although an examination of a lowland sample of the Essequibo is desirable, it is evident that $C$. alta and $C$. saxatilis are not conspecific.

Material examined of Crenicichla alta Eigenmann, 1912. 16 specimens, (British) Guyana, Essequibo River, up to $147 \mathrm{~mm}$ SL (FMNH 53763), as follows:

Holotype: FMNH 53777, 135 mm SL, Gluck Island, 1908.

Paratypes: FMNH 53759, Gluck Island, 6 specimens, 1908; ZMA 100.244, Gluck Island, 1 specimen, 1908; FMNH 53763, Holmia, 5 specimens, 1908; - FMNH 53765, Tukeit, 2 specimens, 1908; - FMNH 53786, Potaro Landing, 1 specimen, 1908.
The status of Crenicichla saxatilis albopunctata Pellegrin, 1904, from Surinam (table I). Pellegrin distinguished this taxon by the presence of many dots on the body: "nombreux points clairs sur le corps" (Pellegrin, 1904: 374). These, however, are commonly found in adult males of $C$. saxatilis. Also the morphometric data (table I) of the Surinam syntype of $C$. s. albopunctata (MNHN 4083) and its meristic data $(23 / 10$ scales on, and 60 scales along the lateral lines, D XVIII.15, A III.10) completely agree with those of $C$. saxatilis.

Although Pellegrin's Surinam syntype undoubtedly is an adult male of $C$. saxatilis, more syntypes were involved, from other river systems in the Guianas. These remaining syntypes have to be identified - awaiting fresh topotypical material - before the status of "albopunctata" can be established satisfactorily.

\section{REFERENCES}

Bцосн, M. E., 1792. Naturgeschichte der ausländische Fische, 6: 3-126, 36 pls. (J. Morino * Comp., Berlin). Eigenmann, C. H., 1912. The freshwater fishes of British Guiana, including a study of the ecological grouping of species and the relation of the fauna of the plateau to that of the lowlands. Mem. Carnegie Mus., 5: i-xix, 1578,103 pls.

Eigenmann, C. H. W. L. Bray, 1894. A revision of the American Cichlidae. Ann. New York Acad. Sci., 7: 607-624.

Fernholm, B. A. C. Wheeler, 1983. Linnaean fish specimens in the Swedish Museum of Natural History, Stockholm. Zool. J. Linn. Soc., 78 (3): 199-286.

Gronovius, L. T., 1756: Museum ichthyologicum, 2: 188, pls. V-VII (Th. Haak, Lugduni Batavorum).

Heckei, J., 1840. Johan Natterer's neue Flussfische Brasilien's, nach den Beobachtungen und Mitteilungen des Entdeckers beschrieben (erste Abtheilung, die Labroiden). Annln. wien. Mus. Naturg., 2: 1-470.

Linnaeus, C., 1754. Museum Adolphi- Friderici Regis Svecorum, Gothorum, Vandalorumque. Haer. Norv. Duc. Slesv. Hols. Storm. Ditm. Com. Oldenb. Delmenhorstiae. \&c. in quo animalia rariora im. primis, et exotica: quadrupedia, aves, amphibia, pisces, insecta, vermes describuntur et determinantur, Latine et Svetice cum iconibus: $\mathrm{i}-\mathrm{xxx}, 1-96,1-8,33$ pls. (P. Momma, Holmiae).

- , 1758. Systema naturae per regna tria naturae, secundum classes, ordines, genera, species, cum characteribus, differentiis, synonymis, locis, 1. Editio decima, reformata: 1-824 (L. Salvii, Holmiae). 
Lowe-McConnell, R. H., 1969. The cichlid fishes of Guyana, South America, with notes on their ecology and breeding behaviour. Zool. J. Linn. Soc., 48: 255302,3 pls.

Nijssen, H., 1966. Ichthyological observations: May and June 1966. In: Progress Reports, Biological Brokopondo Research Project, Surinam, 3: 172-180.

——, 1967a. Ichthyological observations: January-March 1967. In: Progress Reports, Biological Brokopondo Research Project, Surinam, 4: 234-237.

-, $1967 \mathrm{~b}$. Final remarks and tentative list of fish species. In: Progress Reports, Biological Brokopondo Research Project, Surinam, 4: 240-246.
Pellegrin, J., 1904. Contribution à l'étude anatomique, biologique et taxinomique des Poissons de la famille des Cichlidés. Mém. Soc. zool. France, 16: 41-402, pls. IV-VII.

REgan, C. T., 1905. A revision of the fishes of the SouthAmerican cichlid genera Crenicara, Batrachops, and Crenicichla. Proc. zool. Soc. London, 1905: 152-168. Steindachner, F., 1915. Ichthyologische Beiträge (XVIII). Sber. kaiserl. Akad. Wiss. Wien, math.naturw. Kl., (1) 124 (8-10): 567-591.

Wheeler, A. C., 1958. The Gronovius fish collection: a catalogue and historical account. Bull. Brit. Mus. nat. Hist., (Hist. Ser.), 1 (5): 187-249, pls. 26-34.

First draft received: 11 March 1985

Revised draft received: 13 September 1985 